Maria Boguszewicz (D)

Uniwersytet Warszawski m.boguszewicz@uw.edu.pl

\title{
O Sarcófago de Francisco R. Remiseiro: arte medieval, estereotipos femininos e a boneca Barbie
}

\section{Resumen:}

Francisco R. Remiseiro é un artista nado en Galicia que bebe da tradición escultórica deste territorio. Esta tradición baséase principalmente na arte medieval galega e na aportación nacionalista do escultor Francisco Asorey. Porén, Remiseiro entra en diálogo coas correntes máis actuais na arte contestatoria e democrática. A boneca Barbie sírvelle de pretexto para entablar un debate en clave identitaria e feminista.

Palabras clave: Francisco Remiseiro, Galicia, escultura, Barbie, feminismo

\begin{abstract}
:
The Sarcófago of Francisco R. Remiseiro: Medieval Art, Female Stereotypes and Barbie Doll

Francisco R. Remiseiro is an artist born in Galicia who is inspired by the sculptural tradition of this territory. This tradition is based mainly on the Galician medieval art and on the nationalist contribution of the sculptor Francisco Asorey. However, Remiseiro invites his audience to dialogue with the most current trends in challenging and democratic art. The Barbie doll serves as a pretext for a debate on the identity from a feminist perspective.
\end{abstract}

Keywords: Francisco Remiseiro, Galicia, sculpture, Barbie, feminism 
Francisco Remiseiro, autor da obra que é obxecto da análise neste artigo, soe dicir que ao mellor vai pasarse a panadeiro porque o pan sempre se vende e as obras de arte non. A asociación con pan non é nada inocente. $\mathrm{O}$ escultor frecuentemente fala da súa obra en termos de alimento. A arte é necesaria para alimentar a alma. Nun sentido parecido, fala da utilidade do inútil Nuccio Ordine (2015: 7-11) a quen Remiseiro fai referencia por exemplo no programa da radio Carne Cruda (Pérez Cruz, 2014). A lóxica capitalista e o réxime do beneficio económico inmediato converte as humanidades nunha disciplina inútil por non traer directamente o crecemento financeiro e os beneficios materiais. O inútil no sistema liberal non ten razón de ser polo cal debe ser eliminado ou, como moito, reservado para a estreita elite que xa pode permitirse o luxo de satisfacer este tipo de necesidades intelectuais. As consecuencias para a arte son nefastas xa que o que se considera inútil no sistema económico conleva o desprezo social. A sociedade non só non participa nos beneficios espirituais que ofrece a actividade artística (tanto como creadores como receptores das obras de arte), senón que os ignora e non percibe os daños que a falta deles lles fai tanto a nivel individudal como comunitario.

O biograma que facilita o artista na súa páxina web xunto ás presentacións que éste fai nos catálogos das exposicións reza o seguinte:

Dende a súa infancia entra en contacto cos oficios tradicionais ancestrais relacionados co traballo da pedra e da madeira. Éstes marcarán fondamente o seu xeito de entender e de relacionarse coa materia. Na súa obra escultórica a figuración sempre ten sido unha constante. Algunhas das súas pezas establecen unha relación entre a entidade humana e o obxecto, explorando o carácter emocional das súas figuras e tratando de que o expectador sexa capaz de recoñecer nelas, máis cun corpo, unha emoción humana. Un constante e forte contido narrativo sempre marca a súa obra. Éste, unido ó contexto que as rodea, fai que a súa linguaxe figurativa estea cargada dun profundo significado de grande actualidade. As súas obras forman parte de diversas colecións en países como Canadá, España, Polonia, Dinamarca ou Siria. Participou en numerosas exposicións colectivas, feiras de arte así como en simposios internacionais de escultura, entre os 
que cabe citar, a Bienal de Realismo y Figuración Contemporánea, organizada pola Galería Clave no ano 2002, a feira Art Madrid na súa edición de 2008 ou o Simposio Internacional de Escultura de Plawno Puszcza Zielonka (Polonia) en 2012.

Así como se pode apreciar, o autor subliña a conexión cos oficios tradicionais tales como o canteiro, o ebanista ou o carpinteiro. Esta característica achégalle á famosa xeración dos escultores dos 80 e 90 do século pasado da cal o máximo exponente é Francisco Leiro. Á falta da academia de belas artes e do espazocio expositivo en Galicia, os artistas tendían a aproveitar o ámbito artesanal (Rodríguez González, 2004: 9).

De todas formas, para Remiseiro a decisión de permanecer conectado á tradición artesanal é unha elección honesta e conleva un auténtico respeto á tradición local. Dalgún xeito unha forma, Remiseiro reivindica o estatus de artista para o artesán tendo en conta que no Medioevo a escultura (e tamén aínda a pintura) non se contaba entre as artes liberales. Sen o conseguinte prestixio e o debido recoñecemento pertencía aos oficios físicos así como a artesanía hoxe en día. Por tanto, o obxecto de arte para Remiseiro é tanto o obxecto como a arte. De alí que o escultor fale do arte(facto) deixando ver esta idea no seu traballo. A talla directa, as pegadas das ferramentas ben expostas, a tosquedade premeditada así como a fragmentación da figura humana son algúns dos xeitos de testemuñar a distancia que o artista crea entre él mesmo, a escultura e o receptor. Estes recursos explotados frecuentemente na fase modernista e posmodernista da escultura galega (a de Francisco Leiro para dar un exemplo) servían para conectar a arte galega, fortemente vinculada ao movemento nacionalista galego, coas tendencias universais. En troques, o uso dos materiais como madeira e pedra, especialmente o granito, constituían a expresión da identidade propia (Rodríguez González, 2004: 295-300).

A Remiseiro gústalle subliñar que a madeira é unha elección natural para un artista en Galicia onde abundan os bosques. En termos parecidos fala deste material Álvaro de la Vega (Chao, 2010), artista multifacético, cando polos anos 94 e 95 empezou a traballar a madeira. 
O uso ideolóxico do material escultórico é tan antigo como o mesmo nacionalismo galego e foi Francisco Asorey quen o estableceu: "Yo creo que el granito es el material ideal para nuestra tierra, y debiera emplearse con más abundancia y frecuencia, ya que va mejor que nada a nuestro carácter y el que yo veo como algo nuestro" (Mera Álvarez, 2003: 39).

Asorey apoiou a expresión da identidade galega en tres elementos: o material (madeira e granito), a técnica (a recuperación da policromía desde o románico e barroco) e os temas (protagonismo dos campesiños, sacralización do cotiá).

O Sarcófago de Remiseiro (2013), a escultura que é obxecto deste análise, é esculpida de granito e mide $37 / 16 / 15 \mathrm{~cm}$. O tamaño non parece grande pero o peso da pedra é considerabel polo material empregado. $\mathrm{O}$ granito, duro para traballar, ten as súas consecuencias formais, como a tendencia ao bloque e a forma pechada. O seu carácter monumental apunta á trascendencia do contido. $\mathrm{O}$ sepulcro encierra non só á persoa senón todo o legado simbólico que se quere protexer.

O simbolismo católico é unha constante na arte remiseirana. $\mathrm{O}$ mesmo artista recoñece a poderosa influencia que a relixión exerceu sobre el xa que as misas na parroquia co decorado da igrexa rural constituían o seu primeiro contacto coa arte. Pese a unha relación máis ben conflictiva entre a igrexa católica e o galeguismo, que Remiseiro evidencia na súa obra, o artista non se posiciona claramente en contra da relixión. Aínda que podemos observar nalgunhas esculturas (por exemplo Onde está Madonna (2015), Forgotten Arm of Christ (2012) e outras) unhas reflexións manifestas (e non sempre optimistas) acerca da fe e da situación da igrexa na sociedade contemporánea, a actitude de Remiseiro é canto menos ambigua. Hai que recordar neste punto que, pese ao declive do poder eclesiástico, a igrexa segue sendo unha das principais fontes de encargos para os escultores en Galicia. De todas formas, o aparato eclesiástico, que tende a afianzar o seu poder fáctico establecendo as alianzas cos axentes hexemónicos, no caso galego non favorece as aspiracións independentistas. Porén, no Medioevo aínda non existía esta fisura, polo menos na esfera simbólica (hai que lembrar que o período dourado da literatura e cultura coincidiu coa 
decadencia política do Reino de Galicia) e o esplendor da escultura en Galicia relaciónase co apoxeo do poder eclesiástico nestes territorios. Unha época na que a pintura era aínda tratada como a "alternativa barata" (Nagel, 2012: 84) ás obras na madeira, pedra ou metal.

O impacto do Sarcófago reside na xuxtaposición da monumentalidade do granito e da súa forma sagrada co contido físico e simbólico que esta tumba en concreto representa. A asociación coa época medieval e a homenaxe que se lle facía á figura representada no sepulcro produce a disonancia no receptor que contempla neste contexto a unha moza nova, atractiva e vestida de forma moderna. O vestido non é máis curto do que se adoita levar polas rúas na actualidade pero non é apropiado para entrar nunha igrexa. Desta forma se prodúcese a controversia. O escultor italiano Maurizio Castellan defendendo a súa famosísima instalación La Nona Ora dixo: "I'm trying to connect images and tensions to bring together different impulses: I want religion and blasphemy to collide" (en Grovier, 2015: 63). A presencia feminina, con todos os seus atributos, no contexto cristiano é un tanto polémica pero non o é menos no contexto nacionalista.

Os nacionalismos xeralmente, e na situación das culturas sen estado especialmente, explotan a función procreativa da muller para construír o mito da patria a base da representación supostamente matriarcal. Así a femia hembra fica asociada coa fecundidade, tanto no sentido da nai da nación ("matria"), como no da terra que simbolicamente pare a esta nación e que lle da de comer (Castro, Reimóndez, 2013: 76). Curiosamente, nestas mesmas condicións, dáse normalmente outro fenómeno que María Xosé Queizán (1986: 55) califica da ideoloxía da derrota. Boa parte dos movementos independentistas asimila os estereotipos negativos para faceren deles o elemento central da loita. Conforme esta perspectiva, preséntase a nación como o mesías dos pobos oprimidos que grazas aos sufrimentos padecidos no presente adquire unhas competencias salvadoras. $\mathrm{O}$ paralelismo desta visión coa da nai abnegada é patente. Na escultura do período nacionalista o arquetipo é a famosa Santa de Asorey á que aínda se fará referencia máis adiante. Evidentemente, a santa nai é a que pariu a Xesucristo. 
Neste sentido, a escultura galega explota o motivo cunha propensión especial (Pulgar Sabín, 2002, 63-67, 94-109).

A conexión da ideoloxía nacionalista e a representación da muller así como as consecuencias negativas que éesta ten para a parte feminina da sociedade, resúmea atinadamente John Thompson (2009: 174) no seu estudo sobre a memoria na novela galega: "As mulleres son completamente deshumanizadas ao seren convertidas en simples significantes de diferenzas étnicas e nacionais".

A deshumanización non é o único problema. Aparte das consecuencias simbólicas, este procedemento ten uns efectos moi concretos na dimensión práctica. Como observa Aida Rosende Pérez (2008: 254) no seu estudo da iconografía feminina de Irlanda, a simplificación das mulleres nos sistemas de representación nacionalista provoca a súa exclusión da realidade política, social e cultural deste país. A creación de figuras míticas e simbólicas convertese no alibi para omitir as mulleres na historia.

Aínda que Galicia non é unha excepción e o equívoco mito de matriarcado afectou a varios colectivos feministas na mesma situación (para non buscar lonxe en Euskadi onde o efecto foi reforzado polo mito de Mari), manifesta unhas certas características peculiares. Como sinala Carmen Blanco na entrevista concedida a Elvira Fente:

O que existe é un patriarcado específico, como todos, que no noso caso, fronte a outros contextos próximos xeográficamente, mostra trazos como unha importante presenza das mulleres nos espazos públicos (campo, mar, cidade) ou unha forte autoafirmación das mulleres populares e de clase alta a partir dos cales se creou o tópico do matriarcado galaico. (En Fente, 2010: 277).

A mesma investigadora constata unha particular aversión do nacionalismo galego articulado políticamente hacia o feminismo, un rasgo que, pese aos parecidos xerais, o galeguismo non comparte co caso catalán ou vasco por poñer só os exemplos máis próximos (Blanco, 1997: 64).

Volvendo á escultura e a súa representación da muller, un caso paradigmático é, como xa se sinalou, a Santa de Francisco Asorey. 
Este artista, chamado "o escultor da raza", deulle moito protagonismo á muller na súa obra aínda que, por suposto, presentouna de acordo coa perspectiva puramente nacionalista. A mencionada Santa supón o ennobrecemento da campesiña que representa a Galicia supostamente matriarcal. É unha figura tensa e áspera que emana a forza física e espiritual aínda que sexa unha mobilización nacida da desesperación. A súa desnudez non a rinde viciosa, ao revés, parece que precisamente a falta do atractivo físico é o elemento potenciador.

En troques, a rapaza que protagoniza o Sarcófago é a icona do ideal de beleza feminina: a boneca Barbie. Introducida ao mercado en 1959, Barbie revolucionou o mundo infantil feminino. En vez de xogar ás amas de casa que coidan dos seus bebés, as nenas empezaron a manexar as figuriñas das mulleres adultas, independentes, coa súa vida profesional e a capacidade adquisitiva. Como o "primeiro xoguete globalizado" (Pereira Domínguez, Pino Juste, 2005: 1425), desempeñou un papel decisivo na socialización de varias xeracións de mulleres en todo o mundo. A muller do Sarcófago, ao contrario da representada pola Santa asoriana, non ten rasgos diferenciadores, non simboliza á galega senón a calquera rapaza do mundo, a galega incluida. A súa forza discursiva non reside aquí no feito de ser galega, nin sequera de ser muller, senón de ser globalizada. A controversia premeditada da obra consiste na confrontación dos valores que simboliza a época medieval para a cultura galega e a falta de valores que representa o mundo actual especialmente no contexto da diferenciación cultural.

Aínda que, visto o contido do sepulcro, é evidente que se trata da boneca Barbie, o Sarcófago en si pola súa forma exterior fai tamén referencia ao mundo de Disney. A moza está deitada yace no leito como se estivese durmida. A asociación coas princesas de Disney, A Bela Durminte ou Brancaneves, é moi oportuna. Falando da disneyzación das sociedades, David Harvey (2012: 134) sinala a paradoxa das rentas de monopolio que en consecuencia da súa mercantilización perden o seu carácter excepcional que constitúe a base do monopolio. Algúns sinalan, como Linda McDowell (2000: 14) por exemplo, que a globalización potencia as forzas centrífugas e que en ningún tempo como este as diferenzas culturais se manifestaban con tanta vitalidade. 
Porén, a práctica capitalista neutraliza esta diferenciación no proceso da disneyización.

A controversia, segundo Alexander Nagel, é a condición mesma da arte (2011: 2). Definiendo a "controversia" o mesmo autor (2011: 2) precisa: "controversy does not adopt any one agent's position or direction; it describes instead a situation, a state of affairs in which multiple forces are in contention and multiple sides to a question are being taken." Por suposto, este tipo de tensións están ben presentes na historia da arte e ata nas obras máis recentes. Unha idea parecida ao Sarcófago de Remiseiro podemos por exemplo observala no cuadro de Marlene Dumas titulado Dead Marilyn do ano 2008. O símbolo sexual por excellencia, Marylin Monroe, está situada no seu leito de morte nunha situación menos atractiva posible (Grovier, 2015: 55-57). As cores frías, entre branco e azul, e tonos pálidos potencian o contraste do que simbólicamente era a estrela e o que é un corpo en vías de descomposición.

Porén, o Sarcófago de Remiseiro produce o desconcerto non só por confrontar o sepulcro medieval coa icona da cultura popular actual senón pola controversia interna dos mesmos símbolos que participan na confrontación.

O poder adquisitivo de Barbie é consumido únicamente na colección de bens, roupa e complementos principalmente, de cor rosa preferiblemente e débese a súa pertenza a raza branca e clase media alta. Aínda que non sexa moi ortodoxo para un texto de investigación, gustaríame citar aquí un dos chistes que se conta sobre a Barbie e as nenas que xogan con ela. Unha destas rapazas, no chiste en cuestión, pide á súa nai que lle merque aunha boneca de trapos. A nai, positivamente sorprendida, exalta a modestia da filla ao que esta replica:

Modesta?! Hello, a miña Barbie necesita unha doncela!

Seguindo a lóxica do chiste, a Barbie non só necesita a doncela senón que tamén necesita o seu Ken. Barbie é pois inevitablemente heterosexual. A productora Mujeres al Borde explotou este rasgo definidor da moneca na súa curtametraxe $A$ que juega Barbie onde xogando coa imaxe estrereotipada da moneca consegue transformar o sistema heteronormativo do mundo Mattel (Garzón Martínez, 2011). 
O efecto secundario desta operación é a humanización da boneca que, adquirindo os rasgos lésbicos, convértese na protagonista de carne e óso. Ao fin e ao cabo é paradóxico o mesmo feito de que a icona da beleza feminina non sexa humano.

Cando Remiseiro contaba o proceso de realización da escultura, ao falar do modelo, confirmaba a súa condición humana: "tiven que inmobilizala para que permaneza quieta", dicía. O artista vacilou nun principio no título que mudou desde a Barbie Yacente ata o Sarcófago. Deste xeito a boneca non só adquire rasgos humanos senón que ata divinos. A denominación "yacente" evidentemente fai referencia a Cristo morto, un motivo recurrente tanto na escultura (co máximo exponente no terreo español en Gregorio Fernández) como na pintura. O tema require dos artistas unha extrema destreza ao ter que representar un corpo semidesnudo no estado de inmovilidade. A Barbie remiseirana non é tanto inmóvil como inmovilizada polo artista que así expresa o seu control sobre a obra. De xeito que a Barbie é (está) deitada porque así a quere o escultor. A decisión final de bautizar a peza o Sarcófago ten as súas consecuencias para a interpretación. A protagonista desaparece do título polo cal fica na sombra, literalmente, dado o lugar no que está deitada. A asociación coa relixión consérvase pero é menos directa remitiendo ao mundo laico. Desta maneira, a boneca deixa de ser o sustituto de Xesucristo e convértese nun ser humano, dignificado, iso sí, pero igual de humano.

Aínda así, o título non deixa de ser ambiguo. A peza, polo seu tamaño, asemella máis o reliquiario que non seirve para enterrar senón máis ben ao revés, manter vivo o poder espiritual do seu contido. Logo, o suxeito que encerra a peza non parece para nada á reliquia. Como apuntaba o abade Theofrid polo ano 1100, "sen a beleza compensatoria do reliquiario a reliquia en si sería repulsiva na súa fealdade" (Nagel, 2012: 67-68). Deixado de lado o aspecto máis propio dunha pecadora, a modo de María Magdalena se se quere, da protagonista da obra, o problema é que o seu corpo non se descompón. Por moi humanizada que sexa, a atemporalidade da escultura no seu conxunto apunta cara a artificialidade da boneca. O seu corpo non podrece non por ser divino senón por ser de plástico porque ao fin e ao 
cabo Barbie é un xoguete. Resulta pois que a humanización da Barbie non lle engade ao final a dignidade senón que reduce a muller, da que é representación, ao obxecto de diversión.

Porén, e aquí temos outra controversia, para Remiseiro o xoguete pode ser arte tanto como a arte pode ser o xoguete. Para comprobalo, ademais das palabras do mesmo artista, basta con ver algunhas das súas obras como Half-doll half-sculpture ou El problema está siempre en el corazón. A idea do xoguete relaciónase co do arte(facto). Así como unha mesa ou unha cadeira é arte polo modo de realizala ( o artesán-creador) e polos valores estéticos que teñen os obxectos funcionais feitos coa man humana, un xoguete non o é menos se cumpre os mesmos criterios. Polo demais, así como os obxectos de uso corrente, a arte debe servir ao ser humano satisfacendo as súas necesidades espirituais. A confluencia dos obxectos de uso diario e das obras de arte non é, por suposto, innovadora en si e ten unha larga tradición con Marcel Duchamp e os seus ready-made. No caso de Duchamp, o que decidía se unha cousa é a expresión artística ou non, era o prestixio e a autoridade do artista. No enfoque que lle da a esta mesma cuestión Remiseiro, o proceso está invertido. O creador é ben modesto e non se diferencia do artesán no esencial: o proceso de creación e a vocación servidora dun e doutro.

Porén, Barbie non cumpre estes criterios. Nin é creación nin de feito sirve á humanidade. $\mathrm{O}$ seu corpo ideal é feito en cantidades masivas, nunha forma unificada e monótona, por medio de máquinas desprovistas da imperfección da man humana. É o revés da arte. Aínda máis, é a forza destructora que socava os fundamentos da actividade artística, tanto no sentido estético deformando o gusto de xeracións enteiras como nos termos de mercado onde non hai demanda das obras de arte en cantidades suficientes como para dar a comer a un artista modesto e sen recoñecemento amplio.

Remiseiro pois xoga coa boneca dun xeito un tanto malicioso. Ademais de enterrala deliberadamente no sepulcro, disfruta da súa decadencia e do seu destino tráxico. Ao fin e ao cabo, cada Barbie remata nun cubo de basura. No taller do artista hai unha colección de bonecas mutiladas, sen perna, brazo, cabeza ou completamente calvas. Todas 
espidas; indefensas e ridículas na súa imperfección. A idea de artista é a creación, nun futuro impreciso, dunha serie dedicada exclusivamente a Barbie onde todas estas mutilacións se reemplazarían con próteses de madeira, improporcionalmente grandes que provocarían desconcerto e incomodidade. Un motivo parecido, aínda que evidentemente máis sutil, aproveitao John Currin nas súas obras. Na pintura titulada Big Hands do ano 2010 Currin presenta a unha muller que se asocia cunha estrela de porno (Grovier, 2015: 95-96) pero cunhas proporcións de corpo desequilibradas. O que máis destaca son precisamente as mans desproporcionalmente grandes como se pertencesen a outra persoa. De todas formas, a desproporción é case imperceptible de xeito que o espectador non se dá conta do motivo da consternación ata que non lea o título que lle indica a fonte da confusión.

Aínda que Barbie en si non sexa arte, foi aproveitada para construir varias obras que case sempre explotan a controversia basada na "identidade" da icona: o ideal da beleza, a heterosexualidade intrínseca, a inocencia (nas descripcións das bonecas que ofrece Mattel Barbie é con frecuencia denominada "a nena"). Pode servir tamén para revalorizar a arte do pasado (arte exipcio, Hierónimo Bosch). O Sarcófago remite as dúas vertientes. A súa Barbie controvertida intrínsecamente está deitada nun sepulcro que se relaciona co Medioevo.

Alexander Nagel nos seus textos, como Anachronic Renaissance ou Medieval Modern, defende unha relación complexa dos artistas contemporáneos co arte do pasado.

No device more effectively generates the effect of a doubling or bending of time then the work of art, a strange kind of event whose relation to time is plural. The artwork is made or designed by an individual or by a group of individuals at some moment, but it also points away from that moment, backward to a remote ancestral origin, perhaps, or to a prior artifact, or to an origin outside of time, in divinity. At the same time it points forward to all its future recipients who will activate and reactivate it as a meaningful event. (Nagel, Woods, 2010: 9)

Deste xeito Nagel contradíice as perspectivas progresistas e modernistas que intentan prescindir do criterio temporal (2012: 51). 
Remiseiro entende que unha obra de arte funciona en varias dimensións temporais: orixínase nun pasado do que bebe o artista, realízase nun momento concreto pero non só para este momento e para este público senón que apunta cara unha multiplicidade de posibles realizacións e revalorizacións futuras.

$\mathrm{Na}$ colección das esculturas que espuxo Remiseiro está unha que se titula $I$ hold a secret e que contén unha mensaxe escrita, ocultada no interior da peza. O papeliño co texto, que lóxicamente non se sabe o que dice, pódese apreciar desde fora polo buraco da boca. O truco consiste en xogar coa curiosidade do receptor que pode ver o misterio pero non pode descifralo a non ser que se rompa a escultura. Tanto neste caso como no de Barbie xacente no seu propio sepulcro, o artista toma conciencia da pluralidade temporal dunha obra de arte.

O Sarcófago evoca a complexidade temporal da creación artística. O símbolo da contemporaneidade, do mercado capitalista pero ao mesmo tempo da liberación feminista, entra en diálogo coa época medieval que para Galicia conleva unha multitude de contidos. É unha época que ten un significado controvertido para a historia e cultura galegas. De forma que, aínda se ás veces se tende a mitificala, non é seguramente un periodo doado de interpretar e valorar. O mesmo acontece coa protagonista da obra, a boneca Barbie, que, como se subliñou xa antes, encarna tanto os aspectos positivos como negativos dos tempos que corren para as mulleres. En conclusión, o Sarcófago preséntase como unha obra de arte complexa que se presta a múltiples interpretacións e ofrece unha riqueza de lecturas en clave identitaria e feminista.

\section{Bibliografía}

BLANCO, C. (1997), El contradiscurso de las mujeres: historia del feminismo, Editorial Nigra S.L., Vigo.

FENTE, E. (2010), Parir a liberdade: o movemento feminista en Galicia, Alvarellos, Santiago de Compostela.

CAMERON, D. (1991), Francisco Leiro: un toque de significado, Deputación Provincial de Pontevedra, Servicio de Publicaciones, Pontevedra. 
CHAO, J. (2010), Alvaro de la Vega, [on-line] https://vimeo.com/20262212, 1.08.2017.

CASTRO, O. REIMÓNDEZ, M. (2013), Feminismos, Xerais, Vigo.

GARRIDO MORENO, A. (2008), "Escultura, espacio e compromiso", en: Basterrechea, S. (comis.), 5 visións desde os 90 [catálogo de exposición], Consello de Ferrol, Ferrol, pp. 30.

GARZÓN MARTÍNEZ, M.T., "A qué juega Barbie: heterosexualidad obligatoria y agencia cultural", Calle 14: revista de investigación en el campo de arte, 6, Bogotá, [on-line] http://revistas.udistrital.edu.co/ojs/index.php/ c14/article/view/2908/9187, 1.08.2017.

GROVIER, K. (2015), Art Since 1989, Thames\&Hudson, London.

HERVEY, D. (2012), Bunt miast. P: prawo do miasta i miejska rewolucja, Fundacja Nowej Kultury Bęc Zmiana, Warszawa.

HEINCH, N. (2007), Być artysta. R: rzecz o przeksztatceniach statusu malarzy i rzeźbiarzy, Vizja Press\&IT, Warszawa.

McDOWELL, L. (2000), Género, identidad y lugar. U: un estudio de las geografias feministas, Ediciones Cátedra, Madrid.

MERA ÁlVAREZ, I. (2003) Francisco Asorey, Xunta de Galicia, Santiago de Compostela.

NAGEL, A. (2011), The Controversy of Renaissance Art, The University of Chicago Press, Chicago.

NAGEL, A. (2012), Medieval Modern, Thames\&Hudson, New York.

NAGEL, A., WOOD, Ch. (2010), Anachronic Renaissance, Zone Book, New York.

ORDINE, N. (2015), A utilidade do inútil, Faktoria K de Libros, Pontevedra. PÉREZ CRUZ, C. (2014), "La utilidad de lo inútil”, Carne Cruda, [on-line] http://www.carnecruda.es/2014/12/04/la-utilidad-de-lo-inutil/, 14.12.2014.

THOMPSON, J. (2009), As novelas da memoria. T: trauma e representación da historia na Galiza contemporánea, Galaxia, Vigo.

QUEIZÁN, M.X. (1986), "De florido poeta da raza a desflorador racista", A Nosa Terra, 7 [Extra Eduardo Pondal], pp. 55-58.

PEREIRA DOMÍNGUEZ, M. del C., PINO JUSTE, M.R. (2005), "Globalización y educación en valores: aportaciones educativas desde el fenómeno social de la muñeca Barbie", EDUGA: Revista Galega do Ensino, 47, Santiago de Compostela, pp. 1421-1441. 
PULGAR SABÍN, C. (2002), Figuracións-Abstraccións, Nova Galicia Edicións, Pontevedra.

RODRÍGUEZ GONZÁLEZ, M.A. (2004), Os materiais, procesos e formas na escultura galega contemporánea: 1940-1994 [tesis doctoral], dir. M.L. Sobrino Manzanares, Universidad de Santiago de Compostela.

ROSENDE PÉREZ, A. (2008), "La iconografía femenina de Irlanda. Creación y re/construcción de una nación en femenino", Lectora: revista de dones y textualidad, 14, pp. 251-267. 